\title{
COMPARISON OF SUPPORT FOR TRAINING OF EMPLOYEES OF METALLURGICAL COMPANIES IN THE CZECH REPUBLIC AND CHINA
}

\author{
${ }^{1}$ Kateryna LESHCHENKO, ${ }^{2}$ Andrea SAMOLEJOVÁ, ${ }^{3}$ Weixue HAN, ${ }^{4}$ Martin LAMPA \\ 1,2,3,4 VSB - Technical University of Ostrava, Ostrava, Czech Republic, EU, \\ kateryna.leshchenko.st@vsb.cz, andrea.samolejova@vsb.cz,weixue.han.st@vsb.cz, martin.lampa@vsb.cz
}

https://doi.org/10.37904/metal.2021.4292

\begin{abstract}
Metallurgy is one of the main industrial sectors which has a significant effect on the economic development of countries. Through the implementation of modern technologies, globalization has stimulated development of the metallurgical sector and delivered overall changes in the need for human capital and human resource management. The automation of production processes has reduced the number of jobs and added uncertainty to the future of work in this field. The sector's attractiveness as a potential employer has gradually decreased, as has interest in related fields of study. In just a few years, industrial enterprises have experienced a shortage of skilled labour. Both individual organizations and their governments have focused on supporting activities to attract, retain and promote the personal development of employees. The Czech Republic, which is a member of the European Union, has certain advantages in these activities compared to China, which, by contrast, is a world leader in the volume of iron and steel production. The paper investigates the current positions of these two countries in the area of support for employees of metallurgical companies. It examines problematic areas and potential solutions to improve the current situation.
\end{abstract}

Keywords: Metallurgical industry, support, human resource, Czech Republic, China

\section{INTRODUCTION}

Technological development has generally increased labour productivity and the quality of resulting products but also contributed to reduced labour requirements through the automation of most industrial processes [1]. To a degree, this development has also left its mark on the metallurgical industry. For this reason, but also because of the greater physical demands and stress on health in production work, the sector's attractiveness to less qualified workers has gradually decreased and created a shortage of qualified workers required for production and technologies at metallurgical companies.

The thematic area Advanced Machines/Technologies for a Strong and Globally Competitive Industry for the years 2021-2027 covers four application sectors, which include engineering and mechatronics, energy and industrial chemistry in addition to metallurgy. These sectors form the traditional backbone of the Czech economy and contribute significantly to GDP (Mechanical Engineering and Mechatronics), or they are a prerequisite for ensuring the competitiveness of several other sectors, as products used in these sectors (Metallurgy and Industrial Chemistry) are created here [2]. Therefore, the Czech government supports the metallurgical industry both directly and indirectly, by supporting education in related fields.

China, which produced more than a half of the world's steel already in the year 2018 and so it is its largest producer. Therefore also Chinese government strongly supports the metallurgical industry, both in terms of customs policy and education of the necessary skilled labour [3].

The article describes a current position of China and the Czech Republic on the steel market and deals with issues of educational activities in metallurgical companies in the Czech Republic and China. The article also offers recommendations and examples to improve today's situation. 


\section{THE GLOBAL POSITIONS OF THE CZECH REPUBLIC AND CHINA ON STEEL PRODUCTION}

In 2019, world steel production increased by $1 \%$ over the previous year, amounting to 1,880.1 million tonnes of steel. Interestingly, at the end of 2019, steel production fell in all regions of the world except Asia and the Middle East [4],[5].

At the end of 2019, China, as expected, led steel production with 1001.3 million tonnes of steel, while the Czech Republic occupied 30th position globally, with an annual production of 4.44 million tonnes [3]. Czech metallurgical companies are located mainly in the Moravian-Silesian region which is also thanks to this fact the second Czech region as for the location of the largest industrial companies. [6], [7] China also accounted for $53.3 \%$ of global steel production in 2019 [6].

The market situation deteriorated rapidly in February 2020 when China isolated its economy because of the coronavirus outbreak and strict quarantine measures applied in other countries. As a result, steel prices rose in May as the Chinese economy recovered. Growth accelerated in the third quarter, and prices rose almost vertically in the fourth quarter despite the complicated the epidemiological situation around the world. In 2020 , the global price of steel products on average remained at 2019 levels, and in the fourth quarter, prices increased by over $30 \%$ year-on-year [6].

China maintained a positive trend in steel production during the general global downturn. According to Worldsteel, steel production in China increased by $5.2 \%$ in 2020 and 51.7 million tonnes to 1,053.0 million tonnes-a record result. The Czech Republic according to Worldsteel showed a similar positive trend, with total production increasing by $0.6 \%$ to 4.5 million tonnes, the country also rising from 30 th position to 27 th. Interestingly, the Steel Union (an organization which protects the interests of Czech and Slovak steel producers and processors) stated a decline in results, indicating that in 2020, the Czech Republic produced 4.33 million tonnes of steel (Figure 1).

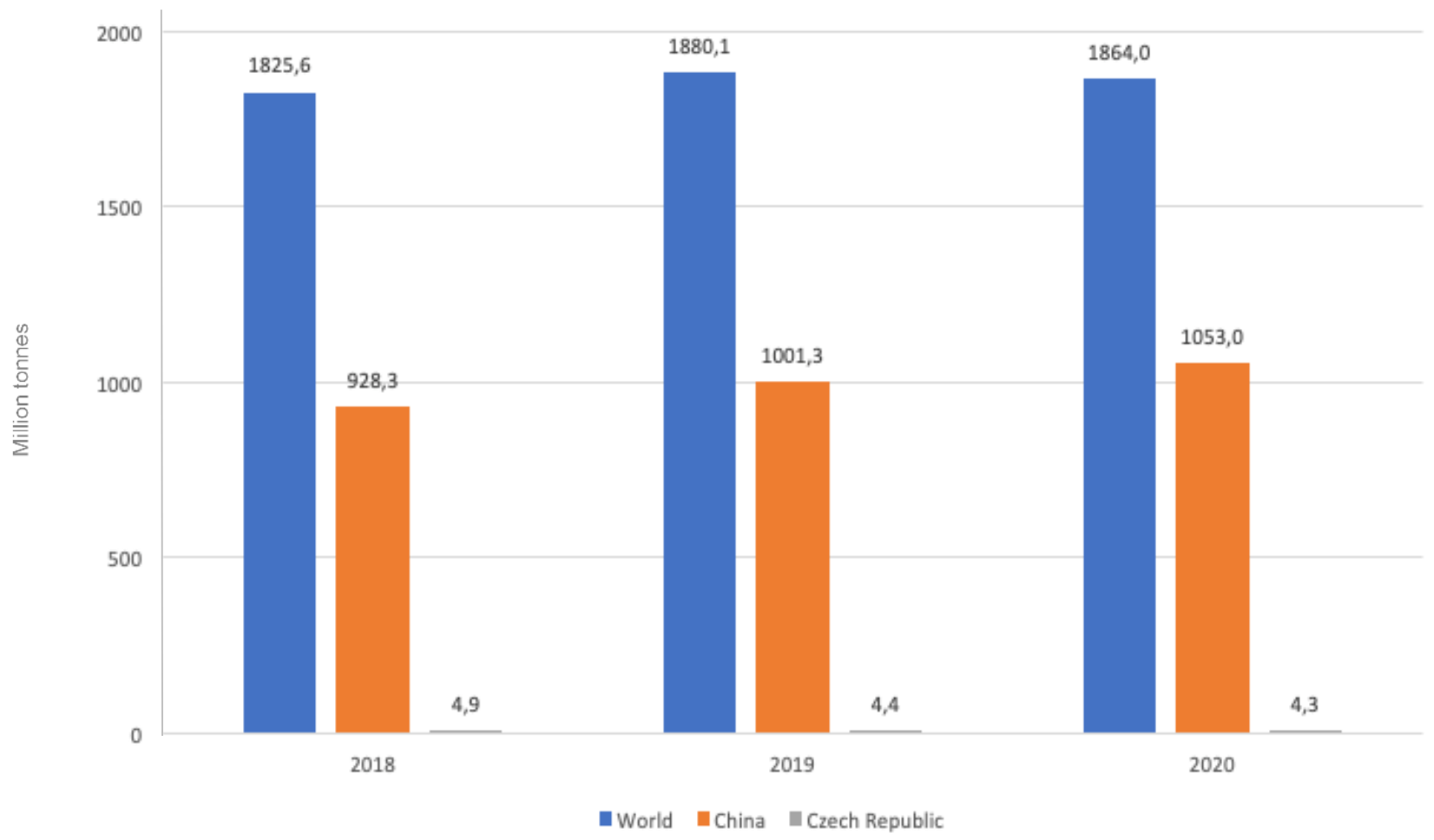

Figure 1 Annual crude steel production (in million tonnes) $[5,8]$ 


\section{SUPPORT IN THE CZECH REPUBLIC AND CHINA FOR THE METALLURGICAL SECTOR WITH HUMAN RESOURCES}

Metallurgical companies in both the Czech Republic and China provide various forms of support for employee training, both internally and externally. Internal training includes formal instruction, work meetings, task assignment, coaching, work rotation, counselling and mentoring. External methods include assistance, lectures with Q\&A, demonstrations, workshops, brainstorming sessions, case studies, PC learning, simulations, assessment centres and role playing. [9]

Studies which investigated staff training and development (T\&D) at Czech metallurgical companies identified that all companies provide some form of education for their employees, while about $90 \%$ create specific plans in this area. In contrast to larger companies, smaller companies create plans for shorter periods and so maintain their flexibility. The proportion is higher at metallurgical enterprises than at other sectors, especially considering that fewer potential employees are graduating from trade-oriented high schools and university programmes focused on the metallurgical industry. These companies therefore have no other option than to recruit unqualified workers and provide them with training and development according to the company's own specific needs. All the companies use both internal and external educational methods. [10], [11]

Weak points have also been identified, for example, no evaluation of the benefits of training and the small use of attractive and efficient educational methods such as coaching, mentoring and role playing. Surveys have shown that companies which invest more time and money in staff T\&D have lower turnover rates and higher employee performance. [10]

In Hubei Province of China, the survey shows that in terms of training awareness, only $4.5 \%$ of frontline workers said that they did not need to receive training to improve their skills, and $63 \%$ of frontline workers said that they had strong training needs at work. However, the current training of high-skilled talents has been focused mainly on School training neglecting the on-the job skill training of employees. Most companies only carry out induction training, safety training, quality training, etc., and do not pay attention to skills training. This is mainly due to two considerations. One is that employers are worried that trained employees will not be able to guarantee corporate loyalty, and they will switch jobs after upgrading their skills. The second one is that onthe-job training may delay work deadlines and also requires companies to invest a certain amount of money.

Due to the lack of skilled labour and the tendency to deepen it, in 2018 the Ministry of Education of China issued instructions for cooperation between vocational schools and metallurgical enterprises. Businesses were encouraged to offer student internships and invest in training of own employees [12]. Jiangxi Metallurgy Vocational Technical College has also been operating in China for a long time, it combines a national advanced unit of vocational education, a national vocational education reform model school, and a national modern apprenticeship pilot college. Relying on the two major Jiangxi state-owned enterprises of Xinyu Iron and Steel Group and Jiangxi Copper Group, the college runs school-enterprise cooperation closely and has been fixed as a training base for the employees of the two companies [13].

Other companies also rely on joint training in vocational colleges or internal classes for skills training, but $50 \%$ of front-line workers are dissatisfied with the training effect, mainly because of the unreasonable curriculum setting, weak teachers, and the lack of training goals and corporate needs. People admit more and more often that joint training within company is just "walking through the scene", a waste of time and energy. Companies did not implement the instructive occupational qualification allowance of the labour department for the levelup skilled workers. It is precisely because most companies do not regard vocational qualification certificates and skill levels as an important basis for internal salary distribution and staffing and have not established a set of incentive and guarantee mechanisms that match the evaluation, training, assessment, treatment and use of skilled talents.

To supplement employee development and bolster overall support for employment in this sector, Czech companies are also taking advantage of the opportunity to obtain financial support from various subsidy 
programmes such as the European Social Fund (ESF). The Employment Operational Programme helps companies implement projects which raise the professional knowledge, skills and competencies of employees. Information about individual ongoing and already completed projects, including the type of educational activity, number of employees and other data, is available freely on the European Social Fund website. Support from the European Social Fund provides more than $50 \%$ of implementation costs. For example, the project "Company education of employees at the company Hutní montáže and partners" included total expenses of CZK 569,280.00, of which CZK 483,888.00 (85\%) was provided by the European social fund. The project supported 12 employees with educational and requalification courses, internships, professional consultation, counselling, training, professional work experience, and so on [14].

As the next example, the company Vítkovické slévárny drew subsidies for the education of its employees from 3 projects [15].

\section{THE WAYS FOR IMPROVING ACTUAL SITUATION}

A high demand for qualified people in manual labour and technical professions exists in both the Czech Republic and China. According to individual studies [10], nor Czech neither Chinese companies have an appropriate qualification for their work position. The shortage of skilled labour for this type of work and the continuing trend in shortage in the coming years has been confirmed by the fact that most manufacturing operation workers and a large proportion of workers overall with a suitable level of education are in the 40-50 age group. Younger generations are more focused on working in administration with computers. This situation is also evident beyond the selected countries. Each country in the world is experiencing similar problems, and all are subsequently applying their own support and training programmes to create more favourable and attractive conditions for work in this field.

In China, at the social level, the government is leading the promotion of the key role and outstanding contribution of skilled talent. It is striving to create socially beneficial conditions and setting the basis of recognition throughout society for highly skilled labour. It aims to build a solid system and policy for the development of such skilled labour. The government should also increase its financial investment in vocational education, encourage students to receive vocational education, provide subsidies for school-enterprise joint education, subsidize skilled labour to improve workers' skills independently, and increase and promote the training of skilled mentors and highly-skilled talent. Enterprises should draft plans for incentives in career development and salary to motivate technical personnel.

In the Czech Republic and China, it would also be appropriate to implement new training procedures and programs that would increase the attractiveness of vocational education for the industry in general and also expand knowledge and competencies in modern technologies among the older generation, which make up a larger share of blue-collar workers. Unfortunately, in both countries, training activities have been so far mostly focused on managers and administrative staff - white collars.

In addition to supporting and developing existing activities, companies could also benefit from practices which are applied in other countries. In Germany, for example, in addition to numerous grant programmes, companies support students from local schools and educational institutions. In practice, this works by the company reaching out to students with an offer of financial support for their education (successful completion of school, university and courses), thereby offering educational activities which would help employees in their work in the future. In such cases, an employment contract may be concluded with the requirement to complete certain courses of study at an educational institution.

Large industrial companies can also benefit from the experience of large companies with own schools or training centres. In this way, companies can offer their own educational programmes reflecting exactly qualification needs of the company. An example of this in the Czech Republic there is Škoda Auto company and its educational institution in Mladá Boleslav. 
Another widespread and successful practice in the field of education of young people, which the Czech Republic and China and their metallurgical companies could currently use are programmes that have been successfully organized in the United States called SYEP. Their labour market for young people has become more demanding and competitive over the last decades, and therefore city or state programmes dependent on government funding have been created to support them. These programmes vary in size and can be relatively large: each summer around 10,000 young people in Boston and over 40,000 in New York are employed in the frame of the programmes. Surveys prove that young people who took part in such programs felt that they were better prepared for future employment. Many also said that they had learned how to manage their emotions, how to ask for help when they needed it, and how to constructively resolve a conflict with a peer. Existing evidence suggests that summer youth employment programmes have the potential to reduce delinquent behaviour, increase academic aspirations and performance, and improve social and emotional development. Compared to more targeted behavioural programs. SYEPs provide work experience that can also lead to future careers or post-secondary education. [16]

\section{CONCLUSION}

Today, both in the Czech Republic and in China, there is a problem of shortage of skilled labour, especially in industrial sectors. Individual states support and implement activities to support education and development of employees in the metallurgical industry, either internally or externally and develop granting programmes reflecting their specific needs. Despite many support measures, a shortage of skilled workers continues in all industries. Governments and individual companies should therefore seek, design and adopt further measures to promote employment and draw on the positive and proven experience of other countries, such as the US Summer Camps for Youth. Investing in skilled workers in the metallurgical industry will certainly pay off for states because according to a 2011 Deloitte study in the USA, each job in the steel industry creates or supports seven jobs in the broader economy both directly and indirectly (in gross numbers, a total of over 1 million jobs in 2011) [17].

\section{ACKNOWLEDGEMENTS}

The work was supported by the specific university research of Ministry of Education, Youth and Sports of the Czech Republic at VSB - Technical University of Ostrava, project no. SP2021/71.

\section{REFERENCES}

[1] HOBSBAWM, E. J. Industry and Empire: From 1750 to the Present Day. rev. and updated with Chris Wrigley (2nd ed.). New York: New Press, 1999.

[2] Ministerstvo průmyslu a obchodu. Národní výzkumná a inovační strategie pro inteligentní specializaci České republiky 2021 - 2027. Přiloha 1. Karty tematických oblastí. [online]. 2021. [viewed 2021-05-24]. Available from: https://www.mpo.cz/assets/cz/podnikani/ris3-strategie/dokumenty/2021/1/B Priloha-1-Karty-tematickychoblasti.pdf

[3] Worldsteel Association. World steel in figures. [online]. 2019. [viewed: 2021-05-22]. Available from: https://www.worldsteel.org/en/dam/jcr:96d7a585-e6b2-4d63-b9434cd9ab621a91/World\%2520Steel\%2520in\%2520Figures\%25202019.pdf.

[4] Worldsteel Association. The Largest Steel Producing Countries. [online]. 2021. [viewed: 2021-03-25]. Available from: https://www.worldsteel.org/en/dam/jcr:e723da20-7c4a-4680-8d2e501c108d7590/Top\%252040\%2520steel\%2520producing\%2520countries.pdf.

[5] Worldsteel Association. The Largest Steel Producing Countries. [online]. 2020. [viewed: 2021-03-25]. Available from: https://www.worldsteel.org/en/dam/jcr:391fbe61-488d-46d1-b611c9a43224f9b8/2019\%2520global\%2520crude\%2520steel\%2520production.pdf. 
[6] Riarating. Reyting stran po proizvodstvu stali. Itogi 2020 goda. [online]. 2021. [viewed: 2021-04-01]. Available from: https://riarating.ru/countries/20210330/630197784.html.

[7] SUCHÁČEK, J., SEĎA, P., FRIEDRICH, V., KOUTSKÝ, J. Regional Aspects of the Development of Largest Enterprises in the Czech Republic.Technological and Economic Development of Economy. 2017, vol. 23, no. 4, pp. 649-666. ISSN 2029-4921.

[8] České noviny. Výroba oceli loni v ČR klesla, propad zmírnilo oživení poptávky. [online]. 2021. [viewed 2021-0510]. Available from: https://www.ceskenoviny.cz/zpravy/vyroba-oceli-loni-v-cr-klesla-propad-zmirnilo-ozivenipoptavky/2006370.

[9] NOE, R. A. Employee Training and Development, 5th ed. New York: McGraw-Hill Irwin, 2010, 589 pp.

[10] SAMOLEJOVÁ, A., ČECH, M. Staff training and development in metallurgical companies. In: 25th Anniversary International Conference on Metallurgy and Materials. Brno: METAL, 2016, pp. 1760-1761.

[11] KOSŇOVSKÁ, Veronika. Analýza efektivity rozvoje a vzdělávání zaměstnanců ve vybrané organizaci. Ostrava: VŠB-TUO, 2015.

[12] Xinhuanet. Feature: China's skilled workers incentivized to succeed. [online]. 2018. [viewed 2021-05-17]. Available from: http://www.xinhuanet.com/english/2018-03/24/c 137061740.htm.

[13] Isacteach. Jiangxi Metallurgy Vocational Technical College. [online]. 2020. [viewed 2021-05-17]. Available from: https://www.isacteach.com/university/jiangxi-metallurgy-vocational-technical-college/

[14] Evropský sociální fond. OP Zaměstnanost 2014 - 2020. [online]. 2014. [viewed 2021-03-28]. Available from: https://esf2014.esfcr.cz/PublicPortal/Views/Projekty/Public/ProjektDetailPublicPage.aspx?action=get\&datovySkla dld=10E214C1-7473-4228-BB31-3D357EF79A79.

[15] Vítkovické slévárny. Dotace. [online]. 2021. [viewed 2021-05-17]. Available from: http://www.vitkovickeslevarny.cz/dotace.

[16] Econofact. Do Summer Youth Employment Programs Work? [online]. 2019. [viewed 2021-05-17]. Available from: https://econofact.org/do-summer-youth-employment-programs-work.

[17] Deloitte. Bridging the talent gap. Engineering a new work force for the U.S. steel industry. [online]. 2014. [viewed 2021-05-17]. Available from: https:/www2.deloitte.com/content/dam/Deloitte/global/Documents/Manufacturing/gxmfg-bridging-talent-gap-steel-industry-report.pdf. 